\title{
PROFESSIONAL PORTRAIT OF FUTURE INSTRUCTORS FOR PHYSICAL EDUCATION OF PRESCHOOL
}

Semanychyn T.M., Popel' S.L.

Prikarpatskiy National University

\begin{abstract}
Annotation. Purpose: identify the degree of readiness of students to conduct valeological activity in preschool educational institutions. The objective of the study was to identify the relationship between educational level and health education and readiness of students to valeological activities. Material: in the experiment took part 550 students. $\underline{\text { Results: }}$ : the survey allowed to establish pedagogical assumptions that characterize the training of students. This will include valeological activity for the formation of their own culture valeological children. It is shown that students' valeological culture is a prerequisite for the effective functioning of the system in pre-secondary institutions. It is noted that the training of students of the Faculty of Physical Education and Sports to valeological activity is low. Conclusions: studies have shown that only $11.7 \%$ of the students have been trained and have the necessary knowledge and practical skills.
\end{abstract}

Keywords: physical education, valeology, culture, children, instructor.

\section{Introduction}

After I.I. Brekhman's [9] introducing of term "valueology as science about health" many specialists try to carry out valueology activity among wide strata of population $[5,10,12]$. With it they pay special attention to children. Recent time valueology knowledge has become integral part of training of highly qualified specialists in system of physical education [8]. Cultivation of students' valueology culture is a core and, at the same time, a determining condition of effective functioning of such system in children educational establishments (CEE).

Valueology orientation of modern education in Ukraine, oriented on a person as the highest value of social being regards him (her) as a subject of cognition, communication and creativity. That is why it is so important to create conditions, in which person would take position of "creator" of own personality in constantly varying modern social environment [11].

The problems connected with formation of valueology culture were elucidated in works of many scientists [1, $3,6]$. Considering their results we can say that training of students at physical culture and sports faculty to valueology functioning corresponds to realization of their own creative potential.

Nowadays term "valueology culture" is interpreted in different ways. It is often is understood as: regulated [7];

- system of knowledge and ideas, on the base of which health related human functioning is constructed and

- high level of ecological thinking, its orientation on HLS, ability to quickly change manner of actions in compliance with new conditions of environment[8];

- special quality, which characterizes measure of certain social role for correspondence of individual's qualities to social standards, which id required for self determination of valueology activity's subject [1];

- one of aspects and, at the same time, axiological potential of personality, who takes position of "creator" of own somatic health in condition of modern social environment $[3,7]$;

- humanistic orientation of modern valueology education in Ukraine with its orientation on a person as the highest value of social being and regards him (her) as a subject of cognition, communication and creativity [11];

- social-psychological setting for non-traditional solution of contradictions of objective reality, connected with practicing of HLS [13];

- integrating and synthetic quality, characterizing the measure of personality's potentials for creative valueology functioning $[2,4]$;

- integral personality's quality, expressed in relation (position, orientation) of a person to own health [15-17];

- combination of real potentials, skills for practicing of HLS, which determine level of valueology education $[5,18-21]$.

From medical point of view valueology culture or culture of health is a part of general culture and is a reasonable system of actions and relations to own health and health of other people, i.e. ability to live not injuring own organism but benefiting it [14]. With it scientists mention that health culture implies not simple "collecting" of useful recommendations but active application of them in everyday practice.

Valueology culture implies also ability to propagate valueology knowledge. Pedagogues shall cultivate firm motivation for health and healthy life style (HLS) starting from pre school age (with the help of academic programs, pedagogic work with parents, with own example in everyday communication).

Thus, it is evident that it is necessary to have interconnection between educational and health related directions in pre school educational establishments. Such interconnection can be ensured by readiness of modern student and future instructor of physical culture in CEE for valueology functioning on the base of system of valueology knowledge, which forms certain level of valueology culture.

\footnotetext{
(C) Semanychyn T.M., Popel' S.L., 2015

http://dx.doi.org/10.15561/20755279.2015.0109
} 


\section{Purpose, tasks of the work, material and methods}

The purpose of the work is to determine the level of readiness of physical culture and sports faculty for valueology functioning.

The main tasks of the research were analysis of scientific literature on theoretical principles of physical culture instructors' training and carry out questioning of students, devoted their readiness for valueology functioning.

The methods and organization of the research. Modern status of training of future physical culture instructors of pre school children for valueology functioning was studied by us with the help of empiric methods, i.e. questioning of 550 HEE students of Ukraine.

The questionnaire had several parts, concerning presence and development of own resources, facilitating formation of valueology culture, strategy and skills in prevention from HLS violation, knowledge of professional valueology culture's structure, its cognitive development, acquiring of personal professional knowledge and creation of functional behavior's strategy. Such construction of questionnaire permits to more completely evaluate problems and disadvantages in theoretical and methodic valueology preparation of future physical culture instructors of pre school educational establishments.

Evaluation was fulfilled by 5-points' scale. All results were processed by methods of parametrical statistics with the help of "Statistika 5" programs.

Results of the research. Discussion.

Characteristics of valueology knowledge are given in table 1. Results of analysis showed that most of the questioned students $(86.7 \%)$ have no oriented understanding of own resources, which would facilitate formation of pre school children's HLS.

Table 1

Characteristics of knowledge and skills of $3^{\text {rd }}-05^{\text {th }}$ year students of physical education and sports faculty in sphere of valueology culture $(n=550, \%)$

\begin{tabular}{|c|c|c|c|c|c|}
\hline Characteristics of knowledge and skills in sphere of valueology culture & +2 & +1 & $\overline{0}$ & 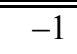 & 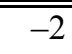 \\
\hline Available personal resources, facilitating formation of valueology culture & 2.1 & 6.8 & 72.3 & 10.9 & 7.9 \\
\hline $\begin{array}{l}\text { Development of personal resources facilitating formation of valueology } \\
\text { culture }\end{array}$ & 6.9 & 12.1 & 69.3 & 5.7 & 6.0 \\
\hline Development of strategy and behavior for prevention of HLS violations & 2.0 & 16.5 & 36.8 & 19.3 & 25,4 \\
\hline \multicolumn{6}{|l|}{ Structure of professional valueology culture. } \\
\hline 1. Cognitive development & 3.0 & 8.1 & 60.5 & 12.0 & 16.9 \\
\hline 2. Development of personal professional resources & 4.6 & 10,3 & 20.1 & 40.4 & 2.6 \\
\hline 3. Development of strategy of functional behavior and skills & 10.2 & 12.5 & 30.3 & 30.6 & $1 . .4$ \\
\hline
\end{tabular}

Question "Do you have own ready system of values, targets and settings in sphere of HLS?" positive answer was given only by $14.2 \%$ of the questioned; "cannot answer" - by $53.4 \%$ : "don't have" - by $32.4 \%$. With it, it was determined that $66.9 \%$ students are not able to communicate with children professionally; $43.2 \%$ do not know how to solve their life problems; $77.9 \%$ - cannot evaluate situations in children collective and cannot use own professional potentials to control such situations. In our opinion this can be explained by quantity of negative points (92.3\%), received by students for their answer to question: "Do you understand behavior of children, render them psychological and social support?"

Low level of valueology fitness of future specialists in pre school physical education is also proved by data about development of personal resources, facilitating formation of valueology culture. More than half $(56.1 \%)$ of respondents have no personal resources, facilitating determination of own mistakes in HLS practicing; $45.6 \%$ points at inability to adequately evaluate problem situations and solve life problems; $68.8 \%$ cannot change themselves and their life; nearly one third (32.3\%) cannot control own behavior and 55.2\% are not able to listen to children.

The latter is explained by the fact that more than $2 / 3$ of students are not able to express own feelings and take decisions on psychological-social children's support.

Such status of students' valueology training reflects in certain way on their ability to work out strategy and behavioral skills for prevention of HLS violations. It was determined that $72.3 \%$ cannot take decisions on overcoming of harmful habits, while $45.3 \%$ do not take such habits as harmful at all. With it only $30.2 \%$ of students can evaluate social situation and feel responsibility for own behavior; $34.7 \%$ can defend own rights and personal space. Insignificant part of students (24.2\%) can defend own "Self", are able for self-support and support. Most students (76.3\%) cannot 
avoid situations, connected with taking harmful substances and other forms of destructive behavior. However $98.6 \%$ of respondent mentioned about ability for non conflict effective communication, including with pedagogues.

Thus, we received answers to three blocks of questions, which touched on characteristics of knowledge and skills in sphere of valueology culture and these answers point at insufficient students' knowledge, at demand in acquiring of such knowledge for successful future professional functioning.

Correction of situation, which exists in this problem, can imply correction of evaluation points with answering on cognitive structure of students' professional valueology education. It was found that holistic idea about processes and phenomena, which occur in nature, only $46.8 \%$ of students have. From them $91.2 \%$ understand potentials of modern scientific methods of cognition of nature. However, only $12.4 \%$ know these methods and are able to apply them in professional functioning. Only $30.1 \%$ have some knowledge about main mental functions of a child, but $78.9 \%$ have knowledge about main human mental functions. So, knowledge of children's psychology requires more attention from the side of pedagogues to students, who are taught to practice valueology activity in pre school educational establishments. Data, concerning development of personal professional resources, were also interesting: $41.1 \%$ of students have skills in analysis of educational situations. Only $23.4 \%$ of them know general philosophical laws of culture of thinking; $26.9 \%$ can express results of educational, scientific and pedagogic functioning both in oral and written forms. Only 37.2 of respondents know national specificities of everyday life, family and family education and can use their knowledge in work. Only one third (33.1\%) of students think that they have high level of personal health and only $11.7 \%$ can feel responsibility for health and life of other people. All these, undoubtedly influence on development of strategy of students' functional behavior and skills in mastering of own valueology culture. Positive answer to question: "Do you know and apply modern methods of scientific cognition?" was given only by $25.3 \%$ from them, while only $10.4 \%$ of respondents know the principles of organizational-sociological researches. Nearly half $(48.7 \%)$ of positive answers were received to question: "Do you have means and methods of pedagogic influence on personality?", with it only $24.6 \%$ from them have knowledge of general and individual features of child's mentality; $22.1 \%$ - use in pedagogic process knowledge of main biological processes, mechanisms, phenomena and etc.

It should be noted that only $25.3 \%$ of respondents consider themselves to be ready for re-evaluation of experience, accumulated by science and social practice in sphere of children's physical education in pre school educational establishments. The most troublesome are students' answers to such challenges of modern system of preschool education as usage of modern informational educational technologies (only $12.3 \%$ of positive answers), knowledge of modern psychological methodic of correction of child's psycho-emotional state (8.9\%), ability to diagnose temper and character of a child (3.4\%), ability to compose psychological characteristic of a child (6.6\%), to personally determine the nearest prospects of a child (5.9\%), determination of psychological climate of children's group $(9.2 \%)$ and sociological; status of a child in group $(7.1 \%)$. Not less troublesome is inability in $63.2 \%$ of cases to determine type of family relations and type of family education. Only $18.6 \%$ of students can carry out work on prevention from family conflicts. With it, it is no surprising that very little part $(3.1 \%)$ of students can compose programs for correction of children's behavior in family. However, rather significant percentage (47.2\%) of students can practically apply knowledge and skills in pedagogic influence on older sociological strata of people. Such status of valueology problem requires integrated program of continuous valueology education for receiving by students both general and basic valueology competences.

Formation of modern strategy of students' functional behavior and skills for formation of own valueology culture is called for also by very low percentage of positive answers to question about ability to create safe and friendly atmosphere in children's collective $(9.5 \%)$, to bring knowledge "between lines", i.e. use non-verbal component of communication (14.2\%), have knowledge of children's styles and methods of material's mastering and great stock of different forms of teaching functioning (4.7\%), are satisfied with work with children and enjoy with it (16.5\%).

Analysis of answers to questions, touching on employment and competence in valueology functioning in $\mathrm{CEE}$ is shown in fig. 1 and 2 .

It was found that staff positions in CEE are engaged by workers from other branches, who passed brief course of retraining as instructors in pre school children physical culture. Answers to first question "Do you agree that owing to deficit of specialists in valueology the appropriate positions are engaged by workers from other branches - coaches, physical culture school teachers, after brief retraining course?" distributed in the following way: from 550 of respondents $48.2 \%$ agreed with our opinion, 32.8\% - agreed partially, 11,7\% - did not agree, for $7.3 \%$ it was difficult to answer.

The second question: "To what extent do you have knowledge about valueology functioning in CEE?" results distributed in the following way: from 550 of respondents only $11.1 \%$ of students have knowledge in this field, $39.2 \%-$ have partial knowledge, $36.8 \%$ - have no knowledge and for $12.9 \%$ of students it was difficult to answer. 


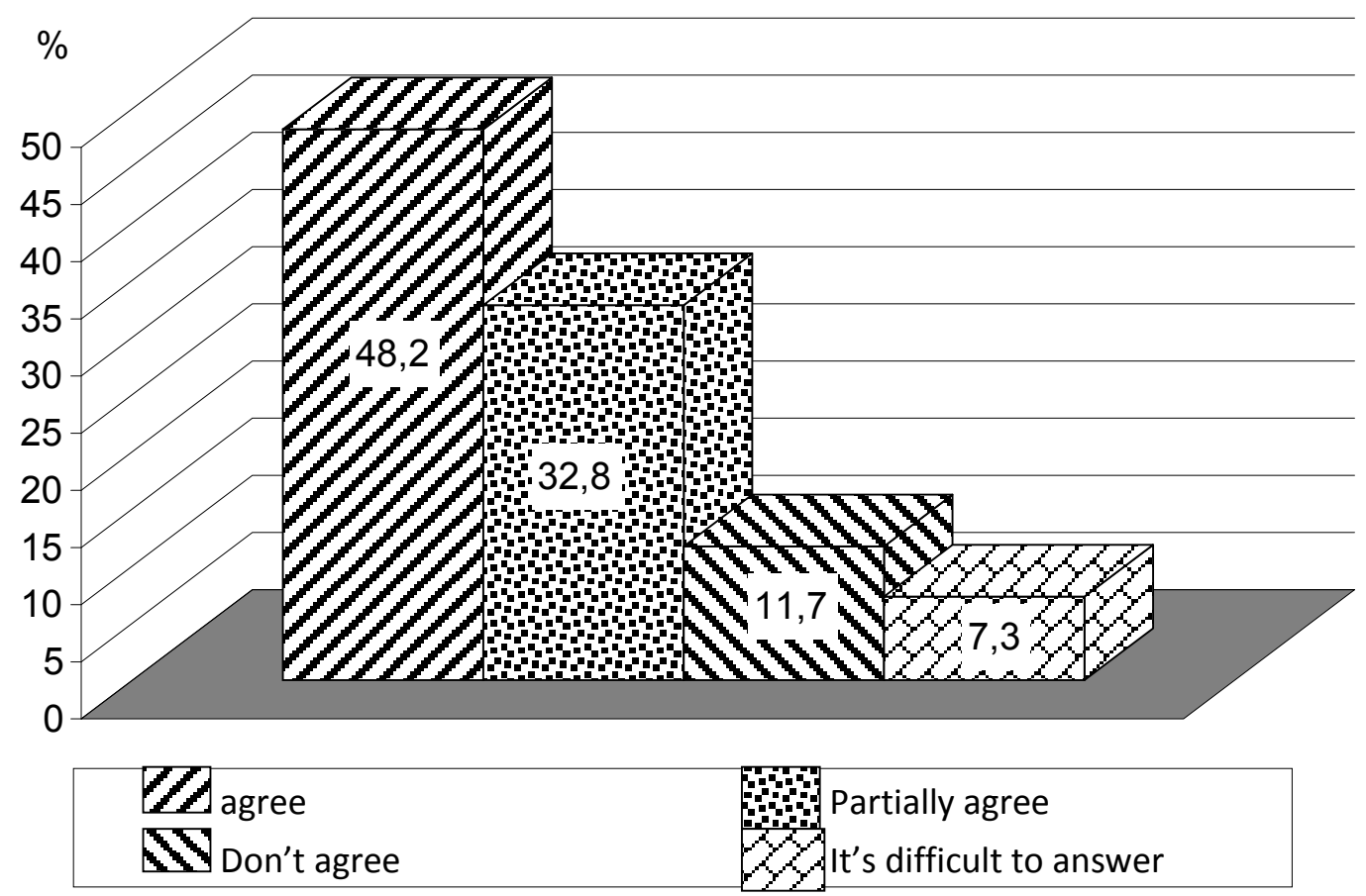

Fig.1. Quantity of students, questioned about staff provisioning for valueology functioning in CEE.

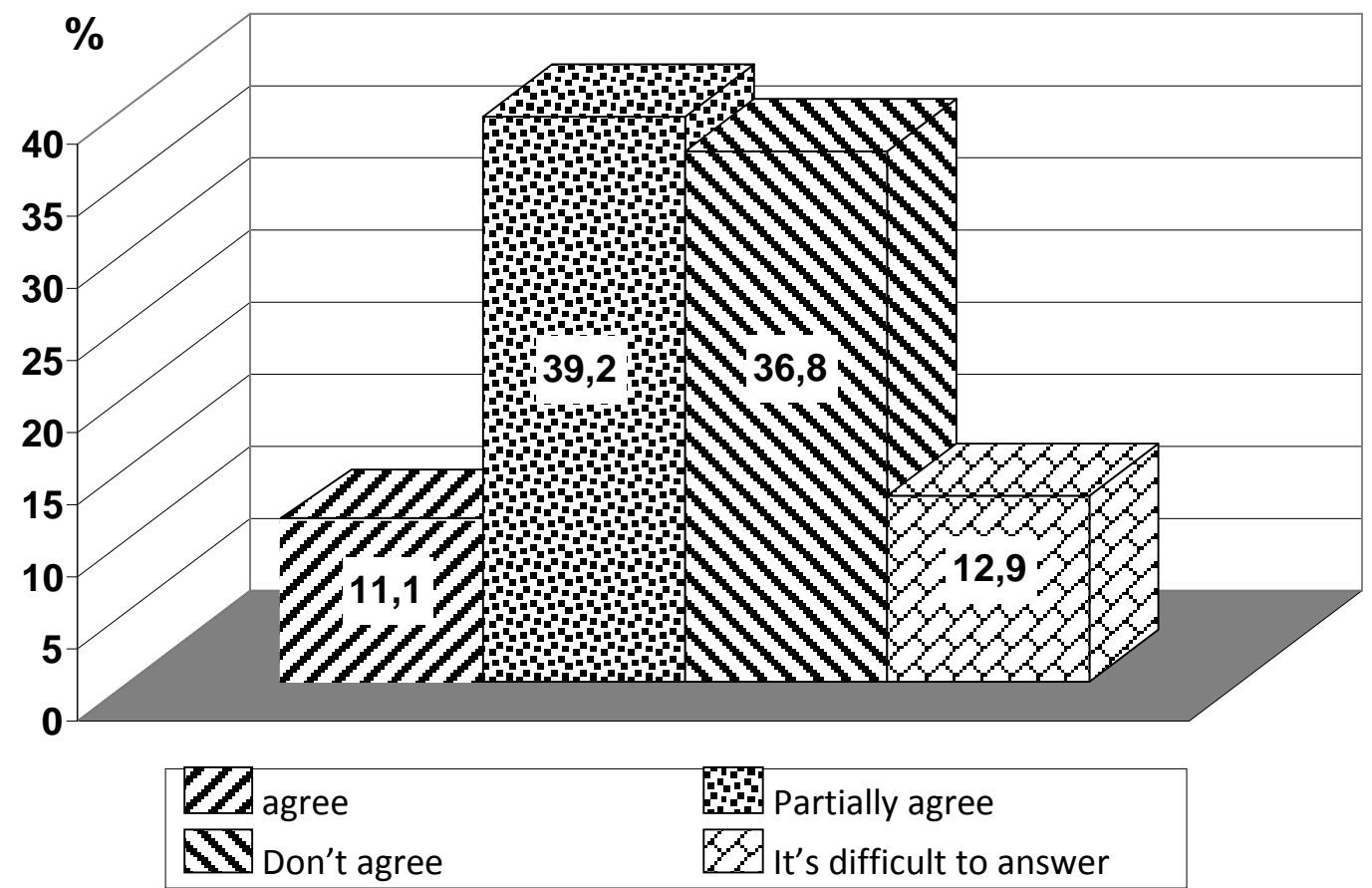

Fig.2. Quantity of students, questioned about knowledge of valueology functioning technologies in CEE (\%).

Therefore, very little quantity of students, videlicet $11.1 \%$, have sufficient level of valuelogy culture and knowledge about valueology functioning in CEE that witness about urgency and purposefulness of this problem. 


\section{Conclusions:}

1. On the base of analysis of pedagogic literature and research of theoretical principles of professional training of future physical education instructors for valueology functioning in CEE we showed that only $11.7 \%$ of the questioned students have proper fitness and required knowledge and skills.

2. Formation of future physical education instructor's readiness for valueology functioning is oriented on opening of higher educational establishment student's potentials to successfully respond to new requirements of social environment.

3. Future physical education instructor in CEE shall be professionally competent creative, humanistic personality with prevailing spiritual-moral qualities and brightly expressed subjective position, individual style of functioning and significant creative potential.

The prospects of further researches in this direction are working out of scientific-methodic complexes for effective training of CEE future physical education instructor for practicing of valueology activity.

\section{References:}

1. Aliev M.N., Gusejnov A.G. Vospitanie nravstvenno-volevykh kachestv u detej sredstvami fizicheskoj kul'tury [Education of moral and volitional qualities in children by means of physical culture]. Pedagogika, 2008, no.1, pp. 67-73. (In Russian)

2. Kovtun R.F. Podgotovka molodykh specialistov vysshikh uchebnykh zavedenij $k$ vospitatel'noj rabote so studentami. Kand.diss. [Training of graduates of higher educational institutions for educational work with students. Cand. Diss.], Chelyabinsk, 2005, 327 p. (In Russian)

3. Korotaeva E.V. Kachestvo podgotovki budushchego pedagoga [The quality of training of future teachers]. Pedagogika [Pedagogy], 2006, no.9, pp. 61-66. (In Russian)

4. Krucevich T.Iu. Teoriia $i$ metodika fizicheskogo vospitaniia [Theory and methodology of physical education], Kiev, 2003, 423 p. (In Russian)

5. Kutek T. [Features of the learning process of future industry professionals "Physical Culture and Sports"]. Molodaia sportivnaia nauka Ukrainy [Young sports science in Ukraine], 2009, no.4, pp. 90 - 94. (In Russian)

6. Kuc A., Tret'iakov M., Lapichak I. Integraciia cennostej fizicheskoj kul'tury v professional'noj podgotovke pedagoga po fizicheskomu vospitaniiu [Integration of the values of physical culture in teacher training in physical education]. Pedagogika, psihologia ta mediko-biologicni problemi fizicnogo vihovanna $i$ sportu, 2003, no.1 pp. 119-124. (In Russian)

7. Martishina N.V. Cennostnyj komponent tvorcheskogo potenciala lichnosti pedagoga [Value component of creative potential of the teacher]. Pedagogika, 2006, no.3, pp. 48-57. (In Russian)

8. Matveev L.P. Teoriia i metodika fizicheskoj kul'tury [Theory and methods of physical culture]. Sankt Petersburg, Lan, Omega, 2004, 159 p. (In Russian)

9. Moskalenko N.V. Innovacionnaia programma razvitiia fizkul'turno-ozdorovitel'noj raboty $\mathrm{v}$ obshcheobrazovatel'nykh shkolakh [Innovative program of development sports and recreation activities in secondary schools]. Sportivnij visnik Pridniprov'ia, 2005 no.2, pp. 37-40. (In Russian)

10. Nikolaev Iu.M. Obshchaia teoriia i metodologiia fizicheskoj kul'tury [General theory and methodology of physical education]. Teoriia i praktika fizicheskoj kul'tury, 2005, no.11, pp. 9-14. (In Russian)

11. About the state and prospects of development of adult education: college decision MES from 27.11.2008, vol. 14 / 3-3. Information Collection MES of Ukraine, 2009, no.1, pp. 31-45. (In Russian)

12. Skarednova I.V. [Development and implementation of modular routines aimed at creating culture of healthy and safe lifestyle of younger students]. Opyt vnedreniia federal'nykh gosudarstvennykh obrazovatel'nykh standartov nachal'nogo obshchego obrazovaniia v Tiumenskoj oblasti [Experience of implementing the federal state educational standards of primary education in the Tyumen region], Tyumen, 2012, pp. 33-36. (In Russian)

13. Solov'ev G.M. Genezis stanovleniia sovremennogo celepolaganiia po fizicheskoj kul'ture v sisteme obrazovaniia [The genesis of the emergence of modern goal setting in physical culture in the education system]. Teoriia i praktika fizicheskoj kul'tury, 2003, no.8, pp. 10-14. (In Russian)

14. Usol'ceva L.A. [Creating the conditions for a healthy lifestyle in a GEF implementing children]. Opyt vnedreniia federal'nykh gosudarstvennykh obrazovatel'nykh standartov nachal'nogo obshchego obrazovaniia $v$ Tiumenskoj oblasti [Experience of implementing the federal state educational standards of primary education in the Tyumen region], Tyumen, 2012, pp. 32-33. (In Russian)

15. Iakovleva I.V. [Actual issues of culture of a healthy and safe lifestyle during the implementation of the GEF]. Opyt vnedreniia federal'nykh gosudarstvennykh obrazovatel'nykh standartov nachal'nogo obshchego obrazovaniia v Tiumenskoj oblasti [Experience of implementing the federal state educational standards of primary education in the Tyumen region], Tyumen, 2012 pp. 30-32. (In Russian)

16. Jang S-J., Tsai M-F., Chen H-Y. Development of PCK for novice and experienced university physics instructors: a case study. Teaching in Higher Education. 2013, vol.18, no.1, pp. 27-39. http://dx.doi.org/10.1080/13562517.2012.678329. 
17. Osova O.O. contribution of native teachers of the second half of the XIX-th century to the working out of the teacher's problem. Pedagogics, Psychology, Medical-Biological Problems of Physical Training and Sports. 2009, no.1, pp. 103 - 105.

18. Sá M.M., Azevedo R., Martins C., Machado O. Portuguese Physical Education Instructors’ Exposure to Noise and Perception of Associated Risk. Human and Ecological Risk Assessment: An International Journal. 2014, vol.20, no.2, pp. 448-460. http://dx.doi.org/10.1080/10807039.2013.786922.

19. Semanyshyn T.M., Popel S.L. The professional valeological portrait of instructor of physical culture. Pedagogics, psychology, medical-biological problems of physical training and sports, 2014, no.10, pp. 41-44. http://dx.doi.org/10.5281/zenodo.10489

20. Whitehead K., Thorpe S. The problematic place of a woman physical education instructor: an historical case study. Gender and Education. 2004, vol.16, no.1, pp. 77-95. http://dx.doi.org/10.1080/0954025032000170354. 
Information about the authors:

Semanyshyn T.M.: http://orcid.org/0000-0001-5043-3208; stmifua@ gmail.com; Prikarpatskiy National University; T.Shevchenko str., 44-a, Ivano-Frankovsk, 76018, Ukraine.

Popel S.L.: http://orcid.org/0000-0001-9019-3966; serg_popel@mail. ru; Prikarpatskiy National University; T.Shevchenko str., 44-a, IvanoFrankovsk, 76018, Ukraine.

Cite this article as: Semanychyn T.M., Popel' S.L. Professional portrait of future instructors for physical education of preschool Physical education of students, 2015, no.1, pp. 60-66. http://dx.doi org/10.15561/20755279.2015.0109

The electronic version of this article is the complete one and can be found online at: http://www.sportpedu.org.ua/html/arhive-e.html

This is an Open Access article distributed under the terms of the Creative Commons Attribution License, which permits unrestricted use, distribution, and reproduction in any medium, provided the original work is properly cited (http:// creativecommons.org/licenses/by/3.0/deed.en).

Received: 10.11.2014

Accepted: 10.12.2014; Published: 30.12.2014 